\title{
КОРЕКЦІЯ ПОТЕНЦІЙНО МОДИФІКОВАНИХ ФАКТОРІВ РИЗИКУ ПРИ ЛІКУВАННІ МЕТОДОМ ГЕМОДІАЛІЗУ: СТАНДАРТИ ЛІКУВАННЯ І ІНДИВІДУАЛЬНІ ДІАЛІЗНІ ПРОГРАМИ
}

І. Л. Кучма

\author{
Національна медична академія післядипломної освіти імені П. Л. Шупика
}

\begin{abstract}
Для створення системи прогнозування ефективності гемодіалізу вивчено можливості коригування потенційно модифікованого фактора ризику смерті пацієнтів, які перебувають на замісній нирковій терапії, методиками проведення гемодіалізу. Зроблено висновки про можливість сучасних діалізних методик ефективно впливати на артеріальну гіпертензію хворих із хронічною хворобою нирок V Д стадії та необхідність подальшого їх вивчення 3 метою розроблення стандартів лікування із застосуванням математичних моделей індивідуальних діалізних програм.
\end{abstract}

Ключові слова: корекція потенційно модифікованих факторів ризику, хронічна хвороба нирок, гемодіаліз, артеріальна гіпертензія, стандарти лікування.

\section{КОРРЕКЦИЯ ПОТЕНЦИАЛЬНО МОДИФИЦИРОВАННЫХ ФАКТОРОВ РИСКА ПРИ ЛЕЧЕНИИ МЕТОДОМ ГЕМОДИАЛИЗА : СТАНДАРТЫ ЛЕЧЕНИЯ И ИНДИВИДУАЛЬНЫЕ ДИАЛИЗНЫЕ ПРОГРАММЫ}

И. Л. Кучма

Национальная медицинская академия последипломного образования

имени П. Л. Шупика

\begin{abstract}
Изучены возможности корректировки потенциально модифицированного фактора риска смерти пациентов, находящихся на заместительной почечной терапии, методиками проведения гемодиализа. Сделаны выводы о возможности современных диализных методик эффективно влиять на артериальную гипертензию больных с хронической болезнью почек $\mathrm{V}$ Д стадии и необходимость дальнейшего их изучения с целью разработки стандартов лечения с применением математических моделей индивидуальных диализных программ.
\end{abstract}

Ключевые слова: коррекция потенциально модифицированных факторов риска, хроническая болезнь почек, гемодиализ, артериальная гипертензия, стандарты лечения.

\section{CORRECTION OF POTENTIALLY MODIFIED RISK FACTORS IN THE HEMODIALYSIS : STANDARDS OF TREATMENT AND INDIVIDUALISED PROGRAMS OF DIALYSIS}

\section{L. Kuchma}

\author{
National Medical Academy of Postgraduate Education by P. L. Shupyk
}

In the effect prognosis of dialysis a possible adjustment of the modified potential death risk factors of patients who are on renal replacement therapy by hemodialysis techniques are discussed. The conclusions about the possibility of modern dialysis techniques to effectively influence on arterial hypertension of patients with chronic kidney disease stage 5 - D and the need for further study in order to develop treatment standards using mathematical models for individualised dialysis programs.

Key words: correction of potentially modified risk factors, chronic kidney disease, dialysis, arterial hypertension, treatment standards.

Вступ. В Україні постійно зростає кількість пацієнтів із хронічною хворобою нирок (ХXН), які отримують лікування методом гемодіалізу. За дани- ми Національного реєстру хворих на хронічну хворобу нирок, ця кількість зросла з 4195 у 2011 році до 4952 у 2012 році. Зростання за 2012 рік склало $18 \%$

(C) І. Л. Кучма 
$[1,2]$. Використання програмного гемодіалізу при термінальній стадії XXН дає можливість не лише продовжити тривалість життя пацієнтів, але й забезпечити його якість. Разом зі зростанням кількості пацієнтів завдяки широкому використанню гемодіалізу не тільки неухильно збільшується тривалість життя хворих із ХХН, але й, відповідно, зростає кількість хворих із різноманітними ускладненнями, що призводять до летальних наслідків. Відповідно до Національного реєстру, кількість померлих зросла з 8,2\% (346 осіб) до 9,6\% (473 особи) [1, 2].

При цьому розподіл хворих за тривалістю лікування, віком, часом лікування, кількістю діагностованих гіпертрофій лівих відділів серця, кількістю пацієнтів із невідкоригованою артеріальною гіпертензією, гіперпараратиреозом, гіперфосфатемією, рівнем гемоглобіну, застосуванням еритропоезстимулювальних препаратів, гепатитами практично залишиився на однаковому рівні. Можна відмітити лише несуттєве зниження за забезпеченістю адекватною діалізною дозою $(1,8 \%)$, за індексом маси тіла $(2,4 \%)$ та зростання використання напівсинтетичних мембран по відношенню до синтетичних (5\%).

У Національному ресстрі не вказана кількість пацієнтів, які отримують лікування сеансами гемодіалізу тривалістю 4, 5, 6, 7 чи 8 годин, 3 чи білыше разів на тиждень, кліренсові та ультрафільтраційні характеристики діалізатора, профілювання концентрації натрію та бікарбонату діалізного розчину, профілювання температури діалізного розчину, пввидкість ультрафільтрації під час гемодіалізу, частоти епізодів інтрадіалізної гіпертензії та гіпотензії, приросту маси тіла за рахунок надлишткової рідини в міждіалізний період, швидкості перфузії крові через діалізатор. Хоча зазначені параметри діалізної програми є факторами, що суттєво впливають на корекцію потенційно модифікованих факторів ризику при лікуванні сеансами гемодіалізу, зокрема, таких, як артеріальна гіпертензія, гіпертрофія лівого шллуночка, міокарда, високий рівень ліпопротеїдів низької щільності, низький рівень ліпопротеїдів високої щільності тощо.

На сьогодні відсутні дані про можливість впливу на ці фактори ризику, а тим самим на зниження летальності пацієнтів, пाляхом зміни частоти проведення та тривалостіпроцедури діалізу, правильного підбору параметрів діалізного розчину тощо, тобто використанням індивідуально підібраних діалізних програм.

Лікування ХХН у термінальній стадії методом гемодіалізу в Україні проводиться відповідно до стандартів та Протоколів МОЗ України, а також до ло- кальних протоколів проведення лікування сеансами гемодіалізу, розроблених на підставі «Уніфікованих клінічних протоколів медичної допомоги лікування пацієнтів з хронічною хворобою нирок V стадії) ДУ "Інститут нефрології АМН України" [3].

При призначенні лікування інтермітуючим діалізом зазначені протоколи передбачають таке:

1. Частота проведення гемодіалізу не рідше 3-х разів на тиждень.

2. Тривалість одного сеансу - не менше 4-х годин. У пацієнтів з ШШКФ більше 2 мл/хв тривалість сеансу може бути зменштена за умови відсутності ознак МIA-синдрому, корекції артеріальної гіпертензії при застосуванні не більше, ніж одного антигіпертензивного засобу, відсутності набряків, гіперфосфатемії та гіперкальціємії.

3. Доза гемодіалізу визначається, як еKt/V. eKt/V повинен становити $\geq 1,2$.

4. Вимоги до мембрани діалізатора:

a) синтетична;

б) стерилізація парою або $\gamma$-випроміненням.

5. Оптимальна швидкість потоку крові через діалізатор - 300 мл/хв, але при цьому не повинно відбуватись зниження тиску в артеріальній магістралі системи менше 150 мм рт. ст.

6. Швидкість потоку діалізуючого розчину 500 мл/хв.

7. Температура діалізуючого розчину залежить від температури навколишнього середовища, температури тіла хворого і показників його гемодинаміки.

8. Вимоги до діалізуючого розчину: а) використовується бікарбонатний діалізуючий розчин (за необхідності можливе застосування ацетатного буфера); б) концентрація натрію діалізуючого розчину залежно від натрію плазми пацієнта; в) концентрація калію в діалізуючому розчині 2 ммоль/л; г) концентрація кальцію в діалізуючому розчині 1,25-1,5 ммоль/л; д) для хворих без цукрового діабету використовується концентрація глюкози діалізуючого розчину 02 ммоль/л; у пацієнтів з цукровим діабетом концентрація глюкози в діалізуючому розчині повинна становити 5,5 ммоль/л.

Зазначені уніфіковані протоколи і навіть локальні протоколи залипгають лікарю ряд завдань, а саме: визначення частоти сеансів гемодіалізу для забезпечення максимально високої якості та тривалості життя; визначення тривалості кожного сеансу для пацієнта; визначення величини діалізної дози; технологію проведення профілювання температури діалізного розчину залежно від температури навколипнього середовища та температури тіла хворого; визначення концентрації натрію в діалізаті залежно від 
натрію плазми пацієнта та концентрацію бікарбонату діалізного розчину враховуючи його кардіо- та вазомоделювальні властивості.

Мета роботи: вивчити вплив зазначених параметрів діалізної програми на корекцію потенційно модифікованих факторів ризику при лікуванні сеансами гемодіалізу, а саме - порівняти ефективність корекції потенційно модифікованого фактора ризику - артеріальної гіпертензії [5] - при використанні індивідуально підібраних програм гемодіалізу та при лікуванні відповідно до уніфікованих клінічних протоколів.

Матеріал і методи дослідження. Під нашим спостереженням перебувало 88 пацієнтів, які були поділені на 2 групи залежно від програмування сеансів гемодіалізу (тривалості лікування, профілювання по концентрації натрію в діалізному розчині, концентрації бікарбонату в діалізному розчині, профілювання швидкості ультрафільтрації, профілювання температури діалізного розчину).

До першої-основної групи - увійшло 50 пацієнтів, у яких на початку лікування була артеріальна гіпертензія чи нестабільність гемодинаміки під час проведення гемодіалізу, протягом 12 місяців і білыше проводилось лікування відповідно до уніфікованих протоколів: частота сеансів гемодіалізу 3 рази на тиждень, тривалість сеансу гемодіалізу більше 4 годин, діалізна доза КT/V більша 1,2, концентрація натрію в діалізному розчині становила 140 ммоль/л, концентрація бікарбонату в діалізному розчині 34 ммоль/л, температура діалізного розчину становила $37^{\circ} \mathrm{C}$, рівень гемоглобіну не менше 90 г/л, через 12 і більше місяців. Пацієнтам, у яких зберігалась артеріальна гіпертензія чи спостерігалась нестабільна гемодинаміка під час сеансів гемодіалізу, було індивідуально підібрано параметри діалізної терапії: частота проведення сеансів становила 3 рази на тиждень, тривалість діалізу - від 4 до 8 годин, діалізна доза KT/V білыша 1,2, концентрація натрію в діалізному розчині складала від 133 до 145 ммоль/л, концентрація бікарбонату в діалізному розчині - від 27 до 34 ммоль/л, температура діалізного розчину становила від $36,6^{\circ} \mathrm{C}$ до $37,3^{\circ} \mathrm{C}$.

Другу (контрольну) групу склали 38 пацієнтів, у яких на початку лікування була артеріальна гіпертензія чи нестабільність гемодинаміки під час проведення гемодіалізу, впродовж 12 місяців і більше проводилось лікування відповідно до уніфікованих протоколів: частота сеансів гемодіалізу 3 рази на тиждень, тривалість сеансу гемодіалізу більше 4 годин, діалізна доза KT/V більша 1,2, концентрація натрію в діаліз- ному розчині становила 140 ммоль/л, концентрація бікарбонату в діалізному розчині - 34 ммоль/л, температура діалізного розчину становила $37^{\circ} \mathrm{C}$, рівень гемоглобіну не менше 90 г/л.

Термін перебування на замісній нирковій терапії в основній групі складав: від 1 року до 5 років - 5 пацієнтів (10\%), від 5 до 7 років -24 (48\%) пацієнти, від 7 до $10 \mathrm{p}-20(40 \%)$ пацієнтів, і більше 10 років1 особа (2\%).

В другій групі терміни лікування гемодіалізом були наступні: від 1 до 5 років -14 (42\%) пацієнтів, від 5 до 7 років - 18 (58 \%) пацієнтів. Причинами, які призвели до виникнення ХХН у першій групі, були: первинний гломерулонефрит - у 26 (52\%), діабетична хвороба нирок - у $16(32 \%)$, полікістоз нирок - у 4 (8\%), пієлонефрит - у $3(6 \%)$ паціснтів. Системні захворювання - 1 випадок ( $2 \%$ пацієнтів), причина ХХН не встановлена.

У другій групі хворих на гломерулонефрит було 26 чоловік (68\%), 8 пацієнтів із діабетичною хворобою нирок $(21 \%), 2$ - з хронічним пієлонефритом (5\%), 1 (3 \%) з полікістозом нирок і 1 з вродженою аномалією нирок (3\%).

Розподіл пацієнтів за статтю в обох групах був рівнозначний, за віковими характеристиками групи також були рівноцінними, вік пацієнтів складав від 36 до 62 років.

Всі хворі отримували лікування в амбулаторному режимі.

Вимірювання артеріального тиску проводили за методом Короткова. Артеріальний тиск вимірювали перед сеансами гемодіалізу та під час сеансу через кожні 20 хвилин.

У всіх пацієнтів за загальноприйнятими стандартними методиками визначали міждіалізні показники сечовини, креатиніну, K, $\mathrm{Na}^{+}$д діалізну дозу (KT/V).

Досліджували також клініко-лабораторні показники-загальний аналіз крові (гемоглобін, лейкоцитоз), рівень білка, наявність диспротеїнемії, рівень альбуміну. Всі ці дані визначали при використанні стандартних протоколів та при проведенні діалізу за індивідуальними програмами.

Результати та їх обговорення. При проведенні лікування за стандартними протоколами в першій групі через 12 місяців після початку лікування кількість паціснтів з артеріальним тиском вище 140/90 мм рт. ст. зменшилась на $26 \%$, в другій, контрольній групі - на $18 \%$.

При цьому в основній групі кількість паціснтів, які приймали один гіпотензивний препарат, зменшилась 
на 1 хворого (2 \%), кількість пацієнтів, які приймали 2 гіпотензивні препарати залишилась без змін - 48\%, проте кількість осіб, які приймали 3 і більше препаратів, зменшилася на $26 \%$.

Отже, правильно підібране лікування із забезпеченням адекватної діалізної дози відповідно до існуючих протоколів дозволяє у 20-30 \% пацієнтів на тлі прийому гіпотензивних препаратів зменшити артеріальну гіпертензію, а також зменшити дозу медикаментів.

У подалышому, при застосуванні індивілуальних програм із зміною концентрації натрію бікарбонату, температури діалізного розчину, часу діалізу і швидкості ультрафільтрації, кліренсової продуктивності діалізатора вдалось зменшити кількість пацієнтів, у яких артеріальний тиск був вищий 140/90, на 93 \% від загальної кількості хворих. При цьому артеріальна гіпертензія залишалась у пацієнтів, в яких до початку лікування артеріальний тиск був 200/100 і вище, або у пацієнтів, котрі не завжди сумлінно виконували лікарські рекомендації. Прицьому кількість пацієнтів, у яких відпала потреба у прийомі гіпотензивних препаратів, зросла до $70 \%$. Частина пацієнтів (20\%) приймали 1 препарат в субтерапевтичних дозах 3 метою профілактики чи кардіопротекції, а у пацієнтів, які приймали 2 i білыше препаратів, використовували ліки із групи антагоністів кальцію та бета-блокатори за рекомендацією кардіолога.

У контрольній групі при подалышому лікуванні суттєвих змін не виявлено (табл. 1, 2).

Таблиця 1. Показники артеріальної гіпертензії в першій групі паціснтів

\begin{tabular}{|c|c|c|c|c|c|c|}
\hline \multirow[b]{2}{*}{ АТ вище 140/90 } & \multicolumn{2}{|c|}{$\begin{array}{c}\text { Перед } \\
\text { ліку- } \\
\text { ванням } \\
\text { сеансами } \\
\text { гемо- } \\
\text { діалізу }\end{array}$} & \multicolumn{2}{|c|}{$\begin{array}{c}\text { Через рік і } \\
\text { більше } \\
\text { після } \\
\text { лікування } \\
3 \text { рази на } \\
\text { тиждень } \\
\text { по } 5 \text { годин } \\
\text { із досяг- } \\
\text { ненням } \\
\mathrm{KT} / \mathrm{V} \geq 1,2\end{array}$} & \multicolumn{2}{|c|}{$\begin{array}{c}\text { Через рік і більше } \\
\text { після лікування із } \\
\text { застосуванням } \\
\text { індивідуальних } \\
\text { діалізних програм із } \\
\text { досягненням } \\
\text { KT/V } \geq 1,2\end{array}$} \\
\hline & 44 & $88 \%$ & 31 & $62 \%$ & 3 & $6 \%$ \\
\hline \multicolumn{7}{|l|}{3 них } \\
\hline Вище 140/90 без застосування гіпотензивних препаратів & 0 & $0 \%$ & 0 & $0 \%$ & 1 & $2 \%$ \\
\hline $\begin{array}{l}\text { Вище } 140 / 90 \text { із застосуванням } 1 \text {-го гіпотензивного } \\
\text { препарату }\end{array}$ & 6 & $12 \%$ & 5 & $10 \%$ & 1 & $2 \%$ \\
\hline $\begin{array}{l}\text { Вище } 140 / 90 \text { із застосуванням 2-х гіпотензивних } \\
\text { препаратів }\end{array}$ & 24 & $48 \%$ & 24 & $48 \%$ & 0 & $0 \%$ \\
\hline $\begin{array}{l}\text { Вище } 140 / 90 \text { із застосуванням } 3-x \text { і більше гіпотензивних } \\
\text { препаратів }\end{array}$ & 14 & $28 \%$ & 2 & $4 \%$ & 1 & $2 \%$ \\
\hline АТ нижче 140/90 & 6 & $12 \%$ & 19 & $38 \%$ & 47 & $94 \%$ \\
\hline \multicolumn{7}{|l|}{3 них } \\
\hline Нижче 140/90 без застосування гіпотензивних препаратів & 1 & $2 \%$ & 0 & $0 \%$ & $35+(12 *)$ & $70 \%(90 \% *)$ \\
\hline $\begin{array}{l}\text { Ннжче } 140 / 90 \text { iз застосуванням } 1 \text {-го гіпотензивного } \\
\text { препарату }\end{array}$ & 1 & $2 \%$ & 14 & $28 \%$ & $10^{*}$ & $20 \% *$ \\
\hline $\begin{array}{l}\text { Нижче } 140 / 90 \text { із застосуванням } 2 \text {-х гіпотензивних } \\
\text { препаратів }\end{array}$ & 2 & $4 \%$ & 6 & $12 \%$ & $2 * *$ & $4 \% * *$ \\
\hline $\begin{array}{l}\text { Нижче } 140 / 90 \text { із застосуванням } 3-x \text { і більше } \\
\text { гіпотензивних препаратів }\end{array}$ & 1 & $2 \%$ & 0 & $0 \%$ & & \\
\hline Всього & 50 & $100 \%$ & 50 & $100 \%$ & 50 & $100 \%$ \\
\hline
\end{tabular}

*_інгібітор АПФ (від 1/2 рекомендованої мінімальної дози) з метою кардіопротекції та запобігання епізодам гіпертензії,

** - пацієнти із антагоністами кальцію та $\beta$-блокатори за рекомендацією кардіологів. 
Таблиця 2. Показники артеріальної гіпертензії в другій групі пацієнтів

\begin{tabular}{|c|c|c|c|c|c|c|}
\hline \multirow[b]{2}{*}{ АТ вище $140 / 90$} & \multicolumn{2}{|c|}{$\begin{array}{c}\text { Перед } \\
\text { лікуванням } \\
\text { сеансами } \\
\text { гемодіалізу }\end{array}$} & \multicolumn{2}{|c|}{$\begin{array}{c}\text { Через рік і } \\
\text { більше після } \\
\text { лікування } \\
3 \text { рази на } \\
\text { тиждень } \\
\text { по } 5 \\
\text { годин із } \\
\text { досягненням } \\
\mathrm{KT} / \mathrm{V} \geq 1,2\end{array}$} & \multicolumn{2}{|c|}{$\begin{array}{c}\text { При подальшому } \\
\text { лікування } 3 \text { рази } \\
\text { на тиждень } \\
\text { по } 5 \text { годин } \\
\text { із досягненням } \\
\mathrm{KT} / \mathrm{V} \geq 1,2\end{array}$} \\
\hline & 32 & $84 \%$ & 25 & $66 \%$ & 24 & $63 \%$ \\
\hline \multicolumn{7}{|l|}{3 них } \\
\hline Вище 140/90 без застосування гіпотензивних препаратів & 0 & $0 \%$ & 0 & $0 \%$ & 0 & $0 \%$ \\
\hline $\begin{array}{l}\text { Више 140/90 із застосуванням 1-го гіпотензивного } \\
\text { препарату }\end{array}$ & 7 & $18 \%$ & 10 & $26 \%$ & 10 & $26 \%$ \\
\hline $\begin{array}{l}\text { Вище } 140 / 90 \text { із застосуванням 2-х гіпотензивних } \\
\text { препаратів }\end{array}$ & 25 & $66 \%$ & 15 & $40 \%$ & 14 & $36 \%$ \\
\hline $\begin{array}{l}\text { Више 140/90 із застосуванням 3-x і більше гіпотензивних } \\
\text { препаратів }\end{array}$ & 0 & $0 \%$ & 0 & $0 \%$ & 0 & $0 \%$ \\
\hline АТ пижче $140 / 90$ & 6 & $16 \%$ & 13 & $34 \%$ & 14 & $36 \%$ \\
\hline \multicolumn{7}{|l|}{3 них } \\
\hline Нижче 140/90 без застосування гіпотензивних препаратів & 0 & $0 \%$ & 0 & $0 \%$ & 0 & $0 \%$ \\
\hline $\begin{array}{l}\text { Нижче } 140 / 90 \text { із застосуванням 1-го гіпотензивного } \\
\text { препарату }\end{array}$ & 3 & $8 \%$ & 8 & $21 \%$ & 9 & $24 \%$ \\
\hline $\begin{array}{l}\text { Нижче } 140 / 90 \text { із застосуванням 2-х гіпотензивних } \\
\text { препаратів }\end{array}$ & 3 & $8 \%$ & 5 & $13 \%$ & 4 & $10 \%$ \\
\hline $\begin{array}{l}\text { Нижче } 140 / 90 \text { із застосуванням } 3-x \text { і більше } \\
\text { гіпотензивних препаратів }\end{array}$ & 0 & $0 \%$ & 0 & $0 \%$ & 0 & $0 \%$ \\
\hline Всього & 38 & $100 \%$ & 38 & $100 \%$ & 38 & $100 \%$ \\
\hline
\end{tabular}

Висновок. Потенційно модифікований фактор ризику смерті, такий як артеріальна гіпертензія, і патологічні процеси та симптоми, не завжди можна ліквідувати при проведенні стандартної процедури інтермітуючого гемодіалізу за програмою: 3 рази на тиждень по 4 години, досягнення діалізної дози $\mathrm{KT} / \mathrm{V} \geq 1,2$ та проведення супутньої терапії (гіпотензивні препарати, фосфатзв'язувальні препарати, пре-

\section{Література}

1. Національний реєстр хворих на хронічну хворобу нирок: 2011 рік/уклад. Н.І. Козлюк, Г.С. Владзієвська, М. В. Кулизький ; Державна установа «Інститут нефрології АМН України», гол. ред. М. О. Колесник-К. : ДУ «Інститут нефрології АМН України», 2012 - 89 с.

2. Національний реєстр хворих на хронічну хворобу нирок : 2012 рік/ уклад. Н. І. Козлюк, С. С. Ніколаснко, М. В. Кулизь- парати 1,25-дигідроксихолекальциферолу, препарати заліза та еритропоетини). Водночас, правильно підібране лікування із забезпеченням адекватної діалізної дози відповідно до існуючих протоколів дозволяє у 20-30\% пацієнтів зменшити артеріальну гіпертензію на тлі прийому гіпотензивних лікарських засобів, а також зменшити їх дозу.

кий ; Державна установа «Јнститут нефрології НАМН України»; гол. ред. М. О. Колесник. - К. : ДУ «Інститут нефрології АМН України», 2013. - 89 с.

3. Про затвердження стандарту та уніфікованих клінічних протоколів надання медичної допомоги зі спеціальності «Нефрологія». Наказ Міністерства охорони здоров'я України від 11 травня 2011 року №280/44. 